\title{
Inteligentna przestrzeń - między smart building a smart city
}

\section{Smart space - between a smart building and a smart city}

\begin{abstract}
Streszczenie
Pojęcie smart city jest obecnie jednym z bardziej popularnych i chwytliwych haseł związanych z procesem rozwoju tkanki miejskiej. Zjawisko to, pomimo iż dotyczy procesów będących przedmiotem zainteresowań architekta/ urbanisty, wykracza poza obszar jego kompetencji. Jest ono przejawem inteligentnej rzeczywistości opartej na cyfrowych sieciach i zachodzących w nich interakcjach. Jej pojawienie się zostało przewidziane pod koniec lat 80. przez dwie koncepcje: wszechobecnego przetwarzania danych i Internetu Rzeczy/Internetu Wszechrzeczy. Infrastruktura inteligentnego miasta czy budynku nie jest kolejną "branżą" uczestniczącą w procesie projektowym. To szerokie innowacyjne spojrzenie, narzędzie, które oddziałuje wszechstronnie na różne aspekty struktury miasta, także społeczne.

Cyfrowa rzeczywistość w postaci sieci urządzeń, czujników i aplikacji powiązanych z Internetem stanowi inteligentną przestrzeń, które wpływa na nasze życie i równocześnie umożliwia wpływ na kształtowanie zmian w realnym świecie.

Abstract

Nowadays, the term 'smart city' is one of the most popular and catchy phrases concerning the process of development of the urban tissue. Despite the fact that this phenomenon refers to processes which fall into the scope of interests of an architect / an urban planner, it goes beyond the competence of these professions. It is a manifest of smart reality based on digital networks and interactions that happen within them. Its occurrence was predicted in late 1980s by two concepts: the concept of ubiquitous computing, and the concept of the Internet of Things / Internet of Everything. Infrastructure of an intelligent city or building is not yet another 'specialty' taken into account in the course of designing. It is a broad, innovative approach, a tool which exerts a comprehensive influence on different aspects of the urban structure, including the social ones. Digital reality, manifested in networks of devices, sensors, and applications connected to the Internet, constitutes a smart space, which influences our lives, and simultaneously enables us to influence changes in the real world.
\end{abstract}

Słowa kluczowe: smart city, inteligentna rzeczywistość, sieci, smart building

Keywords: smart city, smart space, networks, smart building

Współczesny świat podlega wielu zjawiskom gospodarczo-społecznym, wiążącym się z rozwojem technologii informacyjnej (ICT). Sieć tworząca logiczne, elastyczne i zintegrowane systemy stała się elementem niezbędnym, wszechobecnym, a jednoczenie pozornie niewidocznym. Obecna w swojej fizycznej formie pod postacią światłowodów, okablowania, nadajników i odbiorników może być postrzegana przez architektów i urbanistów przede wszystkim jako element infrastruktury, kolejny element techniczny wymagający opracowania projektowo-planistycznego. Jest to częściowo prawda, jednakże infrastruktura ICT znaczy o wiele więcej. Jej obecność i działanie buduje nowy typ przestrzeni, w której kumuluje się szereg aktywności społecznych oraz różnego rodzaju usług. Celem artykułu jest wskazanie źródeł i przejawów nowej inteligentnej przestrzeni oraz jej wpływu na środowisko zurbanizowane.

Technologia informacyjna przez swoje szerokie zastosowanie, dostępność i oferowane usługi przyczynia się do zmian
The contemporary world is subject to a number of socioeconomic phenomena, relating to the development of the information and communication technology (ICT). A network forming logical, flexible, and integrated systems has become an indispensable, ubiquitous, and at the same time seemingly invisible element. Physically manifested in optical fibre, wiring, transmitters, and receivers, it can be perceived by architects and urban planners most of all as an element of infrastructure, yet another technical element requiring a designing and urban planning approach. It is partly true; nevertheless, the ICT infrastructure stands for much more. Its presence and operation builds a new type of space, where a number of social activities and different types of services accumulate. The goal of this paper is to define the sources and symptoms of the new smart space, and its effect on the urbanised environment.

Information and communication technology, due to its broad use, accessibility, and the services it 

pularnych i chwytliwych haset, zwiazanych z zastosowaniem ICT w procesie rozwoju, gospodarowania i zarządzania tkanka miejską są pojęcia smart building i smart city.

Smart building, czyli inteligentne budynki to obiekty o wysokiej jakości architektonicznej w których zastosowano szereg wzajemnie skorelowanych systemów zapewniajacych wydajność, bezpieczeństwo, energooszczędność, rozwiazania dajnosc, bezpieczenstwo, enstooszczednośc, rozwiązania proekolo systemy zarzadzajace budynkiem monitoruja utrzy

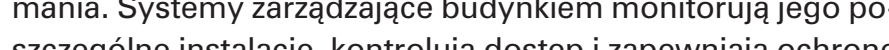
szczegoln iny zaradzajae budykiem monitorua jechopoprzeciwpozarowa oraz antywamaniowa. Glownym celem ich funkcjonowiza jest zapen użk

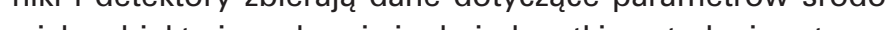
wiska obiektu i przekazują je do jednostki centralnej systemu. Zastosowane oprogramowanie sztucznej inteligencji pozwala na automatyczną reakcję budynku. Miarą jego inteligencji jest zdolność i możliwości samodzielnego reagowania systemu informatycznego budynku na różne stany wywołane zmiana czynników wewnętrznych oraz zewnętrznych. W ten sposób system steruje $\mathrm{np}$. oświetleniem, ogrzewaniem, wentylacja i wietrzeniem pomieszczeń, podlewaniem ogrodu, symuluje obecność mieszkańców, dostosowuje się do ich upodoban i potrzeb, a także reaguje na zagrożenia, jak np. pożar czy włamanie. Jednocześnie z uwagi na energooszczędność i możliwość zmniejszenia oddziaływania na środowisko, inteligentne budynki wpisują się też w nurt budownictwa pasywnego i ekologicznego.

Idea smart city wywodzi się z pojęcia miasta inteligentnego ${ }^{2}$ w którym wykształcona społeczność, zdolna do uczenia się i wdrażania innowacji wykorzystuje technologie informacyjne i sieci sztucznej inteligencji w różnych aspektach życia. Smart city jest strategia zintegrowanego działania na rzecz rozwoju nowego modelu miasta cechujacego sie inteligentnym i holistycznym podejściem do planowania, whtórym zastosowolistycznym podejscie do plaow a , whorym zastosowana infrastru po i zintegrowana platforma smart city, funkcjonuje w postaci

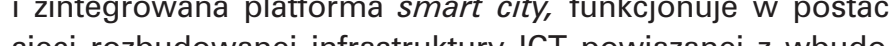
sieci rozbudowanej infastruktury ICT powiazzanej z wbudowany sto w swej fizycznej postaci staje się przestrzenią wyposażona W sensory, detektory, czujniki, czytniki i rozzne urządzenia cyfrowe polączone w sieci. Dzięci systemom zbierającym dane, analizującym je i interpretujacym za pomocą licznych aplikacji, moźliwa jest poprawa komfortu zycia, bezpieczeństwo mieszkańców, a także prognoza potrzeb i zarządzanie miastem. Zbierane dane służą do testowania nowatorskich rozwiązań, umożliwiając zarówno ocenę wpływu technologii na ludzi, jak i reakcję użytkowników na działanie systemów cyfrowych. Poznanie zachowań mieszkańców, jak i udostępnienie im zebranych danych, pozwala realizować różne usługi miejskie np. oświetlenie ulic, wywoz smieci, transport publiczny i dopasować je do odpowiednich potrzeb użytkowników. Z kolei świadomość mieszkańca dotycząca np. jakości powietrza dostępności miejsc parkingowych, godziny odjazdu tramwa- offers, contributes to changes in construction engineering and in the ways in which cities operate influencing the way of life of their inhabitants. Curently, one of the most popular and catchy phrases relating to the application of ICT in the process of development and management of the urban
are the terms smart building and smart city. Smart buildings are buildings which exhibit a hig architectural value, where a series of mutually correlated systems securing effectiveness, safety, energy-efficiency, pro-eco solutions have been applied ${ }^{1}$, reducing long-term maintenance costs. Building management systems monitor its individual installations, control access to it, and provide with fire protection and anti-burglary fittings. The
main goal of their operation is securing maximum main goal of their operation is securing maximum comfort when utilising the building. Sensors and collect data pertaining to the parameters of its environment and forward them to the central unit of the system. The artificial intelligence software adopted in them allows for an automatic reaction of the building. The gauge of its intelligence is the option and ability of the IT system of the building to react to different conditions evoked by changes of internal and external factors. This way the system controls e.g. illumination, heating, ventilation and airing of rooms, watering the garden; it simulates
residents' presence, it adjusts to their habits and needs, as well as reacts to such threats as fire or burglary. Furthermore, due to their energy-efficiency and the possibility of reducing the environmental impact, intelligent buildings also inscribe in the trend of passive and eco housing.

The concept of smart city derives from the notion of an intelligent city' where an educated community, able to learn and implement innovations, makes
use of ICT technologies and Al networks in different aspects of life. Smart city is a strategy of integrated activities for the benefit of development a new model of a city, characterised by a smart an holistic approach to planning, where the applied infrastructure, ICT, and virtual space reflect selected urban activities and functions. Multi-faceted and integrated platform of smart city operates in the form of a network of extended ICT infrastructure linked with embedded measuring devices. In this context, a city in its physical form becomes a space ers, and all sorts of digital devices combined a network. Thanks to systems which collect, analyse, and interpret data via a series of applications, it is possible to improve the comfort of living, residents' safety, as well as to run a forecast of need and manage the city. The collected data are used to test innovative solutions, enabling to evaluate the effect of technology on people, as well as users reaction to the operation of digital systems. Recognition of residents' types of behaviour, as well as provide different municipal services, such as street illumination, garbage disposal, public transport, and to adjust them to relevant needs of users. On the other hand, residents' awareness of $e . g$. the quality of air, availability of parking spaces, time ju i jego aktualnego położenia, lokalizacji oczekiwanej taksówdostosować swoje za nergin, wody, cieńsi do konkretnyc warunków. Smart city wykorzystuje cyfrowa platforme do partycypacji społecznej, zarządzania infrastruktura, testowania i wdrażania najnowszych technologii oraz inżynieryjnych rozwiązań systemowych. Szereg mieddzynarodowych firm jak np. CISCO, IBM, Siemens, INTEL, Philips Electronics, ABB, nych techno rozwiązania dla smart city, wormie zintegrowa-

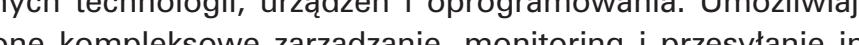
formacii, a takie uczą sie inteligentnie reagować na sytuacje . tyo

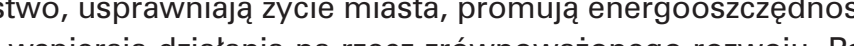
iwstaiv tej najbardzej innowacy.nej formy masta tow. Powstaniu tej najbardiej innowacyjnej formy miasta towarzyszy budowa wysokiej jakosci środowiska miejskiego, o zwartej strukturze wypelnionej zielenia, zapewniająca atrakcyjn miejsca dla pracy, wypoczynku i interakcji międzyludzkiej. Oba opisywane powyżej zjawiska: inteligentne budynk i smart city stanowią przejawy istnienia nowego typu przestrzeni, w ktorej zyje wspólczesny czlowiek. Przestrzeń ta, pomimo że jest niewidzialna i oderwana od pojęcia miejsca, si nie wpływa na swiat realny. Jej funkcjonowanie opiera się na miliardach urządzen rożnej wielkosci, swiatiowodowych sieciach, bezprzewodowych polączeniach i oprogramowaniu. Urządzenia te podłączone do sieci, zapisują i odbierają dan oraz wchodza we wzajemne interakcje tworząc inteligentn przestrzen. Słuzy ona kontaktom interpersonalnym, komunikacji ze sztuczną inteligencją, relacjom poznawczym, świadczeniu usług, rozrywce i rekreacji. Pojawienie sie i rozwoj tej przestrzeni, obecnej w zjawiskach z którymi się stykamy, zapoczątkowały dwie wizje: wszechobecnego przetwarzania oraz Internetu Rzeczy (IoT) /Internetu Wszechrzeczy (loE) Wszechobecne przetwarzanie (ubiquitous computing) to pojecie, które opisuje funkcjonowanie wielu urzadzeń komputeowych w różnch dziedzinach życia. ldea wszechobectego przetwarzania danych powsta in pod koniec lat 80. w Cen-

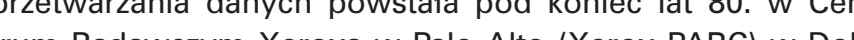
ie Krzemowi w zwiazku z pracani

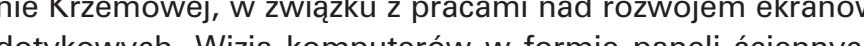
dotykown. Wiza kamp z pracami nad rozwojem ekciennyc

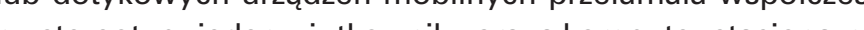
ny stereotyp. jeden użykownik versus komputer stacjonarny i otworzyła dla badaczy PARC koncepcję środowiska, w którym komputery stalyby się wszechobecne, a przez to nieuciąż liwe i niewidoczne. Analizując sposoby, w jakich urządzeni mogą być używane w codziennych sytuacjach, naukowcy sukali mechanizmów włączenia ich w tradycyjne czynności życiowe i powiązanie ze światem zewnętrznym przy jednoczesnym odcięciu się od negatywnych aspektów komputera stacjonarnego.

powszechnienie i rozprzestrzenienie wszechobecnej komputeryzacji wymagało rozwoju niezbędnej technologii w zakresie produkcji tanich, oszczędnych energetycznie komputerów podręcznych, sieci która łączyłaby je ze sobą i system operacyjnego dla implementacji aplikacji. Wszechobecn komputery miały mieć różne wielkości, odpowiednie do tables of a tram and its current location, location of the expected taxi, or the quantity of the consumed energy, water, heat, etc., allows to adjust their behaviour and activities to specific conditions. Smart city makes use of a digital platform of social parimplementing the most advanced technologies and systematic engineering solutions. A number of international corporations, such as e.g. CISCO IBM, Siemens, INTEL, Philips Electronics, ABB, offe such solutions for smart cities, in the form of integrated technologies, devices, and software. They allow for comprehensive management, monitoring, and communication, as well as teach how to react to crisis situation in a smart way. Smart solution mote energy-efficiency, and support activities for the benefit of sustainable development. The for gence of this most innovative form of a city is accompanied by the process of building high-quality urban environment, with a compact structure, filled urban environment, with a compact structure, filled
with greenery, providing attractive places for work, pastimes, and interpersonal relations.

Both phenomena described above: smart buildings and smart cities, constitute symptoms of the existence of a new type of space, where conble and detached from the notion af a place, has a strong effect on the real world. Its operation is based on billions of devices in different sizes, optical fibre networks, wireless connections, and software. These devices, connected to the network record and receive data and interact with each pher, creating a smart space. It supports interpersonal contacts, communication with artificia intelligence, cognitive relations, service provision and development of this space, present in the phenomena we come into contact with, gave rise to (Wo visions: ubiquitous computing, and Internet of Things (IoT) / Internet of Everything (IoE). Ubiquitous computing is a notion which describes different walks of life. The concept of ubiquitous computing of data was coined at the end of the 1980s in the Xerox Research Centre in Palo Alto XEROX PARC) in the Silicon Valley, in connection with works devoted to the development of touchwall pan or mobile touch devices broke the con temporary stereotype of one user versus a desktop computer, and opened to PARC researchers concept of an environment where computers would become ubiquitous, and thus non-burdensome and invisible. Analysing ways in which the devices could be used in the everyday life, scientists were looking for mechanisms of incorporating them in traditional activities and connecting them with the outside world, at the same time cutPopularisation and dissemination of ubiquitous computerisation required the necessary technology to be developed, in the scope of cheap, energy-
efficient hand-held computers, a network which would link them, and an operational system for the 
funkcji, jakie miały pełnić3. Stąd do programu zbudowano powiadające rozmiarom dzisiejszych wirtualnych tablic (Live Board), tabletów (PARC Pad), smartfonów (PARC Tab) czy plakietek (Active Badge). Te cztery typy urządzeń wraz elastyczna infrastrukturą obliczeniową rozpoznającą nazwę urządzenia, jego właściciela, lokalizacje, położenie, funkcje stworzyły infrastrukture roboczą do codziennego użytku w PARC. Jednym z przykładów takiego zasto z pryk w sasiedztwie ekspresu do kawy Każdy zapae PARC świeża kawe naciskał przycisk urzadzenia które japarzający swieżą kaw naciskal przycisk urządzenia, które jednoczesnie oni po napój, co powodowało stałe zgromadzenia wokół ekspresu i przyczynito się do wielu twórczych dyskusji4.

Po wdrożeniu pierwszego eksperymentalnego systemu, jego

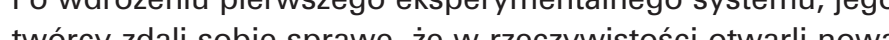
twórcy z dil sobie sp rawg, ze w rzecy wistosic olwarli nową erę i przedefiniowali relacje między ludzmi, maszyna, pracą, technologią i przestrzenia. Tworca koncepcji Mark Weiser przewidywal wơwczas efekty swojego wynalazku: Wszech obecne przetwarzanie okresla trzecią fale komputeryzacji, która wtaśnie się zaczyna. W pierwszej epoce dominowal mainframe, który użytkowało wielu ludzi. Teraz jesteśmy w erze komputerów osobistych, człowiek i maszyna wpatrują się niepewnie w siebie na pulpicie. Następnie zbliża się wszechobecna komputeryzacja lub też epoka cichej technologii, ktora stanie sie ttem dla naszego zycias. Oznaczało to kolejną zmianę w relacji człowiek - maszyna elektroniczna. Rysując tę tendencję, M. Weiser przewidziat sytuację, w której jeden człowiek mógłby korzystać i wchodzić w interakcje z wieloma komputerami, co mogło doprowadzić do zmiany stylu życia.

Trzy dekady później żyjemy w wieku wszechobecnego przetwarzanie danych. Komputer stacjonarny, laptop, tablet, smartfon, czytnik e-booków, samochodowy komputer pokładowy itp. stanowią szeroki wachlarz urządzeń cyfrowych połączonych w sieć i funkcjonujących w rękach jednego człowieka. Gromadzone przez nie dane, zmieniają styl życia ludzi, wpływają na ich decyzje i sposób działania, otwierając drzwi przed Internetem Rzeczy (IoT). Nazwy tej użył w roku 1999 Kevin Aston z MIT opisując system, w którym wszechobecne czujniki wprowadzaja w sieć internetowa szereg danych dotyczących świata fizycznego ${ }^{6}$. Pojęcie to określa wszystkie urządzenia technologiczne, które cechuja się zdolnościa do wymiany danych z innymi ne, które cechują się zdolnoscią do wymiany danych z innymi
aparatami i systemami informatycznymi, umożliwiając diaginfrastrukturą otoczenia człowieka w zależności od panujących warunków i potrzeb. Równolegle firma CISCO wprowadziła terwarunków i potrzeb. Równolegle firma CISCO wprowadziła ter-
min Internet Wszechrzeczy (loE), rozumiany jako inteligentna min Internet Wszechrzeczy (loE), rozumiany jako inteligentna sieć łącząca ludzi, procesy, dane oraz przedmioty? Inteligentna, ucząca się i reagująca na zmiany sieć, otwarta i intuicyjnie
dosteepna a zarazem bezpieczna, odgrywa kluczowa role $w$ loE, dostępna a zarazem bezpieczna, odgrywa kluczową rolę $\mathrm{w}$ loE, obsługując miliardy urządzeń i sprawiając, że połączenia są bardziej trafne. Dziekki temu generuja one nowa

kształcając dane i informacje w realne działania. zainstalowanych w środowisku miejskim i szacuje się, że liczba ta będzie się podwajać w odstępach 5-letnichº Obec- implementation of applications. Ubiquitous computers were to come in different sizes, correspondin to the functions they were to fulfili . Hence, four prototypes in different sizes were built or adjusted fo the purposes of the project, corresponding to the sizes of contemporary virtual boards (Live Board,
tablets (PARC Pad), smartphones (PARC Tab), badges (Active Badge). These four types of devices along with flexible computing infrastructure recognising the name of the device, its owner, location orientation, function, created an operational infrastructure for the everyday life use in PARC. One of examples of this type of application was placing the
PARC Tab in the vicinity of a coffee machine. Each person making fresh coffee pressed a dedicated key on the device, which simultaneously sent relevan information to all workers. They were coming dow stant gatherings around the coffee mabout concontributed to many creative discussions ${ }^{3}$. Having implemented the first experimental system its creators realised that in fact they had launched a new era and redefined the relations between people, machines, work, technology, and space.
The author of the concept, Mark Weiser, foresaw The author of the concept, Mark Weiser, foresaw
the effects of his invention: 'Ubiquitous computing the effects of his invention: 'Ubiquitous computing
names the third wave in computing, just now beginning. First were mainframes, each shared by lots of person and machine staring uneasily at each other across the desktop. Next comes ubiquitous computing, or the age of calm technology, when technoogy recedes into the background of our lives's. This meant another change in the relationship between man and an electronic machine. Sketching this tendency, M. Weiser foresaw a situation where one person could use and interact with many computers Thro could lead to a change of lifesty co. The era ubiqutop, a tablet, a smartphone, an e-book reader, an on-board computer in your car, etc. - they all are a broad array of digital devices linked in a network and operating in the hands of one person. The data they collect change people's lifestyles, influence their decisions and methods, opening the doo before the Internet of Things (IoT). This name was used in 1999 by Kevin Aston from MIT to describ the network a series of data referring to the physica world ${ }^{5}$. This term refers to all technological devices capable of data exchange with other appliances and IT systems, enabling to diagnose, monitor, manag broadly understood infrastructure of man's environment, depending on the prevailing condition and needs. Simultaneously, CISCO introduced the term Internet of Everything (IoE), understood as an intelligent network linking people, processes, data, and objects. An intelligent network, learning and sible, and safe at the same time, plays a key role in $\mathrm{IOE}$, supporting billions of devices and increasin the accuracy of connections. Thanks to this, they generate a new value, transforming data and information into actual operations. nie istnieje w skali globalnej kilka miast, o rozwiniętej intemi i zaawansowanymi technologiami. Najbardziej znanym przykładem smart city jest budowane od początku XXI wieku, Songdo City w Incheon w Korei, ubiquitous city, zaprojektowane przez Kohn Petersen Fox jako jedno z głównych węztów globalnej gospodarki. Ośrodek o powierzchni 600 ha, w większości już zbudowany i stopniowo zaludniany, zostac nów sensorów oraz techno swii informaz obznch. Roz milionia systemowe firmy Cisco umożliwiają centralne zarzadzanie dostawa, utylizacja, transportem i zasobami energii, oszczedzanie wody pitnej, automatyczną segregację odpadów i ich recykling, monitoring i kierowanie ruchem ulicznym, a także indywidualne sterowanie wszystkimi instalacjami w budynkach czy mieszkaniach. Obecnie testowane są systemy telewizyjnej video-komunikacji pomiędzy mieszkańcami, umożliwiające zdalny kontakt i kształcenie. Zlokalizowane w Sondgo Centrum Innowacji Cisco opracowuje kolejne udogodnieni w zakresie opieki zdrowotnej, produkcji $\mathrm{i}$ transportu. Oddziałem Centrum Innowatii jest loT Cube elegancki szklany dzawilon usytum Innowacji jest loT Cube elegancki szklany pawlon usytuowany w jednej z handlowych ulic miasta. Laboratorium gromadzi dane w czasie rzeczywistym, analizuje izbiera opinie mieszkańców Songdo, co umożliwia wdrażanie testowanie roznych rozwiązan i innowacyjnych technolog w mieście. To miejsce stanowi styk dwóch plaszczyzn- realnego miasta i jego inteligentnej przestrzeni, w ktorej napływ informacji pozwala na znalezienia najlepszych rozwiazzań dla potrzeb społeczności i środowiska. Równolegle tej rozwiniętej cyfrowej przestrzeni towarzyszy realna struktura miejska o wysokiej jakości środowiska. Centrum miasta stanow ogromny 40-hektarowy park z kanałami, otoczony wysoka zabudowa usługowa i biurowa. $Z$ parku wychodzi $26 \mathrm{~km}$ tras rowerowych prowadzonych $w$ zieleni do dzielnic mieszkaniowych wyposażonych w ustugi lokalne i tereny rekreacyine. $Z$ kolei w Hiszpanii w latach 2010-2013 w uzdrowiskowo - turystycznym míści y

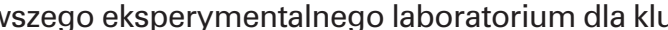
czowych technologii, usług i aplikacji internetowych. W cenrum miasta rozmieszczono ponad 12 tysięcy mikrosensorów połączonych w sieć. Czujniki te stale monitorują parametry klimatyczno-środowiskowe, zanieczyszczenie powietrza, natężenie ruchu samochodowego, dostępność miejsc parkin gowych, nawodnienie terenów zieleni, oświetlenie ulic, liczbe fiają zarówno do władz miejskich, pozwalając na optymalizację działan w zakresie zużycia energii, częstotliwości wywoz icznych aplikacji do mieszkańców i turystów, informująa plazic plaz, ruchu na drogach, pro-

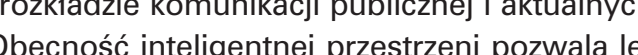
piej zrozumiec dynamike i życie miasta, podnosi jego atrakcyjność oraz ułatwia użytkownikom i turystom korzystanie z jeg。 realnej przestrzeni.
In 2015 there were ca. 15.4 billion devices installed and operating in the urban environment and it is estimated that this number will double every 5 years Today, there are several cities with well-developed smart space in the global scale, full of digital devices and advanced technologies. The best known Korea, built since the beginning of the 21 st century abiquitous city, designed by Kohn Petersen Fox as one of the main hubs of the global economy. The city of the surface area of 600 ha, mostly already erected and gradually populated, is to be completed in 2020. The space of this most advanced city of the world is characterised by the presence of millions of sensors and IT technologies. Systematic solvions mans acthed by CISCO allow Sor centra energy resources, saving potable water, automatic waste segregation and recycling traffic monitoring and management, as well as individual control of all installations in buildings and apartments. Currently, systems of video TV communication between residents are tested so as to enable remote contact and learning. Cisco Innovation Centre located in Sondgo is developing other improvements in the scope of healthcare, production, and transport. Io of the shopping streets of the city, is a brong one the Innovation Centre. The lab collects data in real time and analyses and collects opinions of Songdo residents, which allows to implement and test different solutions and innovative technologies in the city. This place is a contact point of two planes a real city and its smart space, where the inflow of information allows to find the best solutions for the needs of the local community and the environment. At the same time, this well-developed digital space guality environment The city centre is occupied by 40 ha park with canals, surrounded by tall service and office buildings. $26 \mathrm{~km}$ of cycling lanes originate from the park and lead across green areas to and recreational areas.

In Spain, on the other hand, in the years 2010-2013 in a spa and tourist resort Santander, the SmartSantander Project was implemented, finance from structural funds of the European Union mental laboratory for key technologies, services, and Internet applications. Over 12 thousand microsensors combined in a network were installed in the city centre. These sensors constantly monitor climatic and environmental parameters, air pollution, traffic intensity, accessibility of parking spaces, irrigation of green areas, illumination of streets, quantity of waste in waste bins, and the level of overcrowding of streets. The data reach the city authorities, allowing to optimise operations rewaste disposal or of watering of the municip greenery, as well as via a number of applications addressed to city residents and tourists, communicating in real time the condition of beaches, traffic, weather forecasts, public transport timetables, 
W środowisku miejskim smart city, czujniki są instalowane zarówno w częściach budynków (elewacje, podłogi), elementach małej architektury (kosze na śmieci, lampy uliczne), w sieciach infrastruktury miejskiej (światta drogowe, wagony komunikaci miejskiej, sieci wodociaggowe, kanalizacyjne, elektryczne itp.). Dostarczane przez czujniki informacje, dostępne publicznie poprawiaja komfort mieszkańców, a ich analiza staje sie podstawą do działań władz i służb miejskich, rozwoju nowoczesnych aplikacji czy wzrostu postawy obywatelskiej.

Opisane wyżej postawy można zauważyć w Krakowie, w któOpisane wyżej postawy można zauwazye w Krakowie, w którym od kiku lat reali mozię projekty smart city, wdrazany wrzez Krakowski Park Technologiczny, Urząd Miasta Krako$\mathrm{KOM}^{9}$ opracowano programu wdrażania inteligentnych rozwiązań oraz zrealizowano dwa programy pilotażowe: aplikacje mobilną prezentującą szereg innych aplikacji funkcjonucje mobilną prezentującą szereg innych aplikacji funkcjonu-
jących w Krakowie oraz minipark-modułowy element małej jących w Krakowie oraz minipark-modułowy element małej
architektury funkcjonujący jako miejsce rekreacji i wypoarchitektury funkcjonujący jako miejsce rekreacji i wypo-
czynku oraz wprowadzający zieleń w przestrzeń publiczną czynku oraz wprowadzający zielen w przestrzen publiczną
miasta. Rozwojowi idei smart city w Krakowie towarzyszy szereg spotkań $\mathrm{i}$ warsztatów służących poszerzeniu wiedzy, poszukiwaniu pomystów, i rozwiązań w celu wypracowania nowych inteligentnych "produktów”. Od 2011 wdraża się na obszarze całego miasta program firmy Siemens sterujący i zarządzający ruchem tramwajowym ${ }^{10}$. Program składa się z dwóch elementów: Obszarowego Systemu Sterowania Ruchu, zarządzającego sygnalizacją świetlną oraz Systemu Nadzoru Ruchu Tramwajowego, monitorującego tramwaje i przekazującego dane na tablice przystankowe. Oba systemy umożliwiaja punktualny ruch tramwajów dzięki automatycznemu sterowaniu sygnalizacją świetlną oraz informacja o ruchu tramwajów w czasie rzeczywistym, wyświetlana na przystankach. Analiza tych danych i zarejestrowane w systemie opóźnienia przyczyniaja sie do reakcji służb miejskich i poszukiwania sposobu rozwiązania niedogodności. Przykładem takiego działania zwrotnego jest założenie separatorów ruchu na ulicy Kalwaryjkiej oddziejacych ruch satochodowy od torów tram chodow $80 \%$ opóźni (nowalowal znaczną poprawe plynosci przejazdów do poziomu około 62-76\% prlestęp do liwi niez Systrm programistom opracowante ap liwii niezależnym programistom opracowanie aplikacji mapowej przeznaczonej na urządzenia cyfrowe wyświetlającej W czasie rzeczywistym aktualne położenie tramwajów ${ }^{12}$. Drugim elementem, który mocno wplyną na życie mieszkańców i pobudzenie ich obywatelskiej postawy jest punktowy monitoring zanieczyszczenia powietrza prowadzony przez Wojewódzki Inspektorat Ochrony Srodowiska w Krakowie. Dane spływające zaledwie z kilku stacji, nie odzwierciedlają dokładnie stanu środowiska $w$ mieście, ale ich udostępnienie poprzez strony internetowe $\mathrm{i}$ aplikacje ${ }^{13}$ uświadamiaja dramatyczny poziom skazenia powietrza. Te dane wpłynęły nie tylko na podejmowane przez mieszkańców jednostkowe działania jak ograniczenie aktywności fizycznej czy noszenie masek antysmogowych, ale także przyczyniły się do powstania ruchu społecznego Krakowski Alarm Smogowy. and current events. The presence of smart space allows to better understand the dynamics and life of the city, improves its a thractiveness, and makes easier for users and tourists to use its actual space. In the urban environment of a smart city sensors are installed in parts of buildings (on elevations, lamp posts), in municipal infrastructure networks (traffic lights, public transport cars, water supply pipelines, sewage systems, electric installations, etc.). Information provided by these sensors ac cessible to the public improves residents' comfort, and its analysis becomes the foundation for operations of the municipal authorities and municipa services, the development of advanced applications, or the growth of the civic attitude.

The approach described above can be observed city projects have been conducted, implemented by the Cracow Technology Park, the Cracow City Hall, and Małopolskie Province. Within the scheme of the SMART KOM strategy ${ }^{8}$ an agenda of implementation of smart solutions has been developed and two pilot projects have been carried out: a mobile application presenting a number of other applications operating in Cracow, and a minipark as a place of recreation and pastines and introas a place of recreation and pastimes and introdevelopment of the concept of a smart city in $\mathrm{Cra}$ cow is accompanied by a series of meetings and workshops aimed to broaden the knowledge and to look for ideas and solutions in order to develop new smart 'products'. Since 2011 the programm of Siemens controlling and managing the tram traffic has been implemented within the area of the entire city. The programme consists of two elethe traffic lights, and the Tram Traffic Supervision System, monitoring trams and forwarding data tram stop electronic displays. Both systems enable the timely movement of trams thanks to automatic control of the traffic lights and information on the tram traffic in real time, displayed at tram stops. Analyses of these data and delays registered in the system contribute to the reactions of municipa services and stimulate the search of ways to solve any inconvenience that might arise. An example of rators in Kalwaryiska street, separating car traffic from the tramway due to a considerable share of delays ( $80 \%$ of all rides). This measure has caused a considerable improvement in the tram traffic fluency to the level of $62-76 \%$ of timely rides ${ }^{10}$. On the other hand, access to the data from the Transport Traffic Supervision System has enabled independent programmers to develop a map applicatio intended for digital devices, displaying the curren location of trams in real time ${ }^{11}$. The second elemen stimulated their civil attitudes is the point mes and ing of air pollution, carried out by the Provincia Environmental Protection Inspectorate in Cracow. Data flowing from only several stations do not reflect accurately the condition of the environmen
Ruch ten prowadzi kampanie uświadamiające wagę proble. Efektem jego akcji oraz permanentnego nacisku na władze samorzadowe jest uchwal

Komputer powoli przestaje być meblem stojącym w konkretnym miejscu w zorganizowanej przestrzeni domu czy biura. Staje sie jednym z najbardziej niezbednych przedmiotów zycia codziennego, noszonym w torebce, kieszeni w stale zycia codzíci w zasiegu reki. Whaściciel smatfoni w statej życia codzientimo yz do swojego urzadze. Stuzy ono jie tylko jako śązakomunikcil, ale pozwa spawzén zanieczyszcze nie powietza, informuje inachalicie o zawatosci skrzynki mailowej, kome

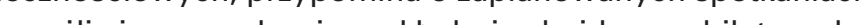
mu munikacji publicznej, informuje gdzie $w$ danej chwili znajduje się oczekiwany tramwaj czy zamawiana taksówka, realizuje platnosci, umozliwia zakupy, ulatwia zarzadzanie infrastukturą domu, liczy spalone kalorie, podsumowuje całodzienną aktywność fizyczną, wysyła nagrody i napomnienia, dostarcza rozrywki i wiedzy. Słowem podłączony do sie stale dostarcza swojemu użytkownikowi szeregu danych ktore nie zawsze potrzebne, wpływają na jego stan wiedzy, samopoczucie, czy podejmowane czynnosci. Jednocześnie urządzenie gromadzi i wysyła do sieci szczegółowe dan o swoim użytkowniku, jego zainteresowaniach, miejscach które odwiedza, czytanych stronach internetowych, trasach po których się porusza itp. co niesie za sobą zagrozenie utraty prywatności, możliwości kontroli z czego człowiek nie zawsze zdaje sobie sprawę czy pamięta. Te dane posiadaja duża wartość i w niepowołanych rẹkach moga stać się niebezpieczne.

Inteligentna rzeczywistość, niewidzialna moc obliczeniowa tworzy równoległą przestrzeń, która pomimo swej niemate(a) i miasta. Stają się one hybrydą o dualnej strukturze, łącząca fizyczna realną strukture z inteligentna przestrzenią wzbogacającą jego funkcje. Dualizm strukturalny miasta - fizyczny i wirtualny, szczególnie w dużych ośrodkach, coraz częście wzajemnie się uzupełnia i przeplata, wpływając na zmiane rozumienia przestrzeni, czasu, styl życia miasta i jego mieszkańców. Procesy zapoczatkowane $\mathrm{w}$ formie pionierskich rozwiązań w realizacjach smart city powoli bẹdą się rozprzestrzeniać i obejmować swym zasiegiem coraz większą liczb miast. Nasza przyszłość bedzie się rozgrywać $w$ inteligentne przestrzeni.

PRZYPISY

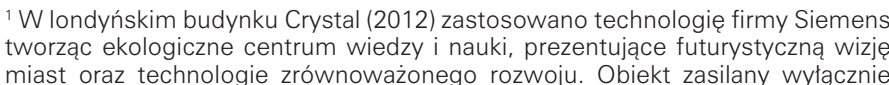
miast oraz technologie zrównowazionego rozwoju. Obiekt zasilany wytacczie mi (akredytacja LEED I BREEAM) a jednocześnie wysokim stopniem automaty zacil (systemy BMS I KNX)
2 Polskie wyrazenie miasto inteligentne ma w jezzku angielskim dwa odpowiedni-
ki intelligent cityi ismart city opisuiace dwie odmienne koncepcie wspótczesnego in the city; nevertheless, when rendered available via websites and applications ${ }^{12}$ they alert about the dramatic level of air contamination. Thes data have influenced not only residents' one-of actions, such as limiting their physical activity, or uted to the establishment of a social movement called Cracow Smog Alert. The movement organises campaigns highlighting the importance of the problem and implements measures aiming to limit emissions. The effect of its work and its permanen pressure on the local governmental authorities is the fact of resolving anti-smog regulations in the city and the province.

Computer gradually ceases to be a piece of furniture located in a specific place in an organise home or office space. It is becoming one of the carried in a handbag, a pocket, constantly accest sible, constantly at hand. An owner of a smartphone, although he /she may not even realise it is strongly attached to his / her device. It is used not only as a means of communication, but it also enables to check the weather forecast, air pollution; it informs importunately about the contents of the mailbox, comments and events in the soit enedia; it reminds about planned meetings for public transport: it informs where the train or a taxi one is waiting for is at the moment: it executes payments, allows to do shopping facilitates the management of one's home infrastructure; it counts burnt calories, summarises daily physica activity, sends prizes and rebukes, provides with entertainment and knowledge. In short, when connected to the network, it keeps providing its user with a number of data which - although no the sense of wellbeing, or decisions concerning undertaking specific activities. At the same time, a device collects and sends to the network detailed data about its user, his/her interests, places the user visits, websites the user reads, routes along which the user moves, etc., which poses a threat of losing privacy, of the possibility of control, and users often do not realise it or simply do not remember about it. These data are very valuable and can become dangerous if handle unauthorised parties.

Smart reality, invisible computing capacity, creates has its effect on our habits, behaviour, and which changes the structures we inhabit - our homes and cities. They become hybrids with a dual structure, combining a physical realistic structure with dualism of the city - physical and virtual - especially in large cities, more and more often is mutually complementary and intertwined, influencing the city and its residents. Processes commenced as trailblazing solutions in smart city projects will be gradually disseminated and will cover more and more cities. Our future will take place in the smart space. 
miasta opartego na rozwoju branży ICT. Autorka używa polskiego wyrażenia miasto inteligentne w odniesieniu do pojęcia inteligent city, natomiast wyrażenie smart city pozostawia w wersji angielskiej.

${ }^{3} \mathrm{M}$. Weiser, The Computer for the Twenty-First Century, Scientific American, Sept. 1991, pp. 94-10

${ }^{4} \mathrm{M}$. Weiser, R. Gold, J. S. Brown The origins of ubiquitous computing research at PARC in the late 1980s, IBM SYSTEMS JOURNAL, VOL 38 NO 4,1999 p 693-696

${ }^{5} \mathrm{http}: / / w w w . u b i q . c o m / h y p e r t e x t /$ weiser/UbiHome.htm

${ }^{6} \mathrm{~K}$. Aston, That 'Internet of Things' Thing, za: www.rfidjournal. com/articles/view?4986

www.cisco.com/c/pl pl/about/press/press-information-2014/20140127.html

${ }^{8}$ Complimentary Whitepaper: IoT Platforms - Enabling the Internet of Things - IHS Markit za: H. Clancy, 10 companies moving up in smart buildings, artykuł z dnia 19.12.2016, www.greenbiz.com ${ }^{9}$ Strategia SMART_KOM opracowana przez Krakowiski Park Technologiczny, powstała w ramach projektu "SMART KOM. Kraków w sieci inteligentnych miast", współfinansowanego przez UE z MRPO 2007-2013

${ }^{10}$ Początkowo od roku 2009 system ten był testowany wyłącznie na linii Krakowskiego Szybkiego Tramwaju.

${ }_{11}$ A. Łaczek, Po montażu separatorów na Kalwaryjskiej tramwaje zaczełty przestrzegać rozkładów, artykuł z dnia 03.04.2017 na portalu www.Ibikekrakow.com

12 Uruchomiona 17.04.2017 strona internetowa: https://mpk.jacekk.net/map.html oraz powstałe kilka dni później aplikacje: KRK Tram Map i Kraków pod ręka

${ }_{13}$ Przykładowe strony internetowe: monitoring.krakow.pios.gov. $\mathrm{pl}$ smog.imgw.pl, powietrze.malopolska.pl, powietrzewkrakowie. pl, przykładowe aplikacje: Zanieczyszczenie powietrza, Powietrze Kraków, Smog w Krakowie, SmokSmog, Kraków Smog

\section{LITERATURA}

11] Chan S., Innovation has the smart city of Songdo living in the future, artykut z dnia 26.01.2016, na portalu www.newsroom.cisco.com

[2] Necombe T., Santander: The Smartest Smart City, artykuł z maja 2014 na portalu www.governing.com

[3] Wdowiarz-Bilska M. Od miasta naukowego do smart city [w: Czasopismo Techniczne z. 1-A/2, Kraków 2012, s. 305-314,

[4] Wdowiarz-Bilska M., Idee miasta w kontekście rozwoju gospodarki opartej na wiedzy [w:] Czasopismo Techniczne z. 12-A, Kraków 2015, s. 223-239

[5] Weiser M., Gold R., Brown J. S., The origins of ubiquitous computing research at PARC in the late 1980s, IBM SYSTEMS JOURNAL VOL 38 , NO 4, 1999 p 693-696

[6] Weiser M., The Computer for the Twenty-First Century, Scientific American, Sept. 1991, pp. 94-10

7] www.smartsantander.eu

[8] www.songdo.com

\section{ENDNOTES:}

1 The London-based building Crystal (2012), where Siemens technology is used, is an ecological centre of knowledge and science, presenting a futuristic vision of cities and sustainable development technologies. The facility uses exclusively solar energy, is heated by heat pumps, is equipped with effective water management and waste recycling fittings, exhibits high ecological standards (LEED and BREEAM accreditation), and at the same time a high degree of automation (MBS and KNX systems).

${ }^{2} \mathrm{M}$. Weiser, The Computer for the Twenty-First Century, Scientific American, Sept. 1991, pp. 94-10

${ }_{3}$ M. Weiser, R. Gold, J. S. Brown The origins of ubiquitous computing research at PARC in the late 1980s, IBM SYSTEMS JOURNAL, VOL 38, NO 4, 1999 p 693-696

${ }^{4}$ http://www.ubiq.com/hypertext/weiser/UbiHome.htm

$5 \mathrm{~K}$. Aston, That 'Internet of Things' Thing, after: www.rfidjournal.com/articles/view?4986

${ }^{6}$ www.cisco.com/c/pl_pl/about/press/press-information-2014/20140127.html

7 Complimentary Whitepaper: IoT Platforms - Enabling the Internet of Things - IHS Markit after: $\mathrm{H}$. Clancy, 10 companies moving up in smart buildings, article dated 19 Dec. 2016, www.greenbiz.com

${ }^{8}$ SMART KOM strategy developed by the Cracow Technology Park came into being within the scheme of the project 'SMART KOM. Cracow in the Network of Smart Cities", co-financed by the European Union from the Małopolskie Region Operational Programme UE z MRPO 2007-2013

${ }^{9}$ Initially, since 2009 the system was tested only on the line of the Cracow Fast Tram.

${ }^{10}$ A. Łaczek Po montażu separatorów na Kalwaryjskiej tramwaje zaczęty przestrzegać rozkładów, article dated 03 April 2017, www.lbikekrakow.com 11 Website https://mpk.jacekk.net/map.html launched on 17 April 2017 and applications launched several days later: 'KRK Tram Map' and 'Kraków pod ręką'

${ }_{12}$ Examples of websites: monitoring.krakow.pios.gov.pl, smog.imgw.pl, powietrze.malopolska.pl, powietrzewkrakowie.pl, examples of applications: Zanieczyszczenie powietrza, Powietrze Kraków, Smog w Krakowie, SmokS mog, Kraków Smog

\section{BIBLIOGRAPHY}

[1] Chan S., Innovation has the smart city of Songdo living in the future, artykuł z dnia 26.01.2016, na portalu www.newsroom.cisco.com

[2] Necombe T., Santander: The Smartest Smart City, artykuł z maja 2014 na portalu www.governing.com

[3] Wdowiarz-Bilska M., Od miasta naukowego do smart city [w:] Czasopismo Techniczne z. 1-A/2, Kraków 2012, s. 305-314,

[4] Wdowiarz-Bilska M., Idee miasta w kontekście rozwoju gospodarki opartej na wiedzy [w:] Czasopismo Techniczne z. 12-A, Kraków 2015, s. 223-239 [5] Weiser M., Gold R., Brown J. S. The origins of ubiquitous computing research at PARC in the late 1980s, IBM SYSTEMS JOURNAL, VOL 38, NO 4, 1999 p 693-696

[6] Weiser M., The Computer for the Twenty-First Century, Scientific American, Sept. 1991, pp. 94-10

[7] www.smartsantander.eu

[8] www.songdo.com 